\title{
A Systematic Review of Neurovascular Complications in Patients with Pseudoxanthoma Elasticum
}

\author{
Colin M. Domzalski ${ }^{1}$, Nancy W. Wei ${ }^{1}$, Mark G. Lebwohl, MD ${ }^{1}$
}

${ }^{1}$ The Kimberly and Eric J. Waldman Department of Dermatology, Icahn School of Medicine at Mount Sinai Hospital, New York, NY

\section{ABSTRACT}

Background: Pseudoxanthoma elasticum (PXE) is a rare, hereditary connective tissue disorder characterized by ectopic calcification of multiple organ systems. Cardiovascular complications secondary to accelerated atherosclerosis are well-documented in published literature; however, there is a paucity of studies that reviews serious neurovascular complications including CVA(cerebral vascular accident), TIA(Transient ischemic attack), and intracranial aneurysm in PXE patients.

Objective: To review current literature reporting cases of serious ischemic and hemorrhagic neurovascular complications in PXE patients as of September 2020 and reexamine current guidelines on antiplatelet therapy in PXE patients

Methods: A search of the PubMed database limited to English language case reports using the key words "pseudoxanthoma elasticum", "neuro", "cerebr", "CVA", "TIA", and "aneurysm" was performed.

Results: A total of 67 cases of cerebral disease were reported; ranging from ages 2-71 years from 12 countries. The most common neurovascular complication seen was ischemic stroke $(68.7 \%)$ followed by TIA (20.8\%), intracranial aneurysm (6.0\%) and lastly hemorrhagic stroke $(4.5 \%)$.

Conclusions: PXE patients have a greater incidence of ischemic strokes compared to the general population. Clinicians should thus monitor this patient population for signs of neurovascular complications and carefully weigh the benefits of antiplatelet therapy in patients with known neurovascular disease against the risk of bleeding.

\section{INTRODUCTION}

Pseudoxanthoma elasticum (PXE) is a rare connective tissue disorder characterized by fragmentation and ectopic calcification of elastic fibers in the skin, ocular, and cardiovascular systems. The disease is linked to loss of function mutations in the $A B C C 6$ genes and has a prevalence of 1 in 160,000 with a 2:1 female to male ratio. ${ }^{1,2}$ Although there exist sporadic reports of acquired PXE, the majority of cases are inherited in an autosomal recessive fashion. ${ }^{3}$ Characteristic cutaneous and ophthalmic manifestations of PXE include the presence of yellow papules in a linear or reticular pattern that often coalesce into larger plaques most commonly overlying flexural surfaces and angioid streaks in Bruch's membrane, respectively. ${ }^{4}$ Additionally, gastrointestinal and retinal 
hemorrhages are notable complications of PXE that generally result in the avoidance of long-term antiplatelet therapies in these patients. ${ }^{5}$ Paradoxically, PXE patients are known to be at greater risk than the general population for coronary artery disease and peripheral artery disease, likely secondary to PXE-associated calcification and atherosclerosis. $^{6}$

Less commonly described in the literature are cerebrovascular complications resulting from PXE: ischemic infarction, intracranial aneurysm formation, and intracranial hemorrhage that can occur even in absence of aneurysm. Although these serious neurovascular events have the potential to result in permanent disability or death, current guidelines do not recommend prophylactic antiplatelet therapy for PXE patients due to the low incidence of these acute events and aforementioned risk of hemorrhage. Our systematic review of the literature aims to describe the prevalence and spectrum of neurovascular complications that may arise in PXE and use this context to re-examine current practice and guidelines regarding antiplatelet therapy in PXE patients.

\section{METHODS}

We performed a PubMed search using the key words "pseudoxanthoma elasticum", "neuro*", "cerebr", "CVA", "TIA", "stroke" and "aneurysm" and limited our investigation to case reports and cohort studies appearing in the English-language literature. (Figure 1) Articles with an irrelevant publication type such as literature reviews, conference abstracts, posters and editorials were excluded. Articles wherein the full text was not available were excluded from review. We reviewed case descriptions appearing in the full text of 10 case reports and 5 cohort/cross-sectional studies in which adult and pediatric patients diagnosed with PXE presented with neurovascular complications including ischemic and hemorrhagic CVA, TIA and intracranial aneurysm.

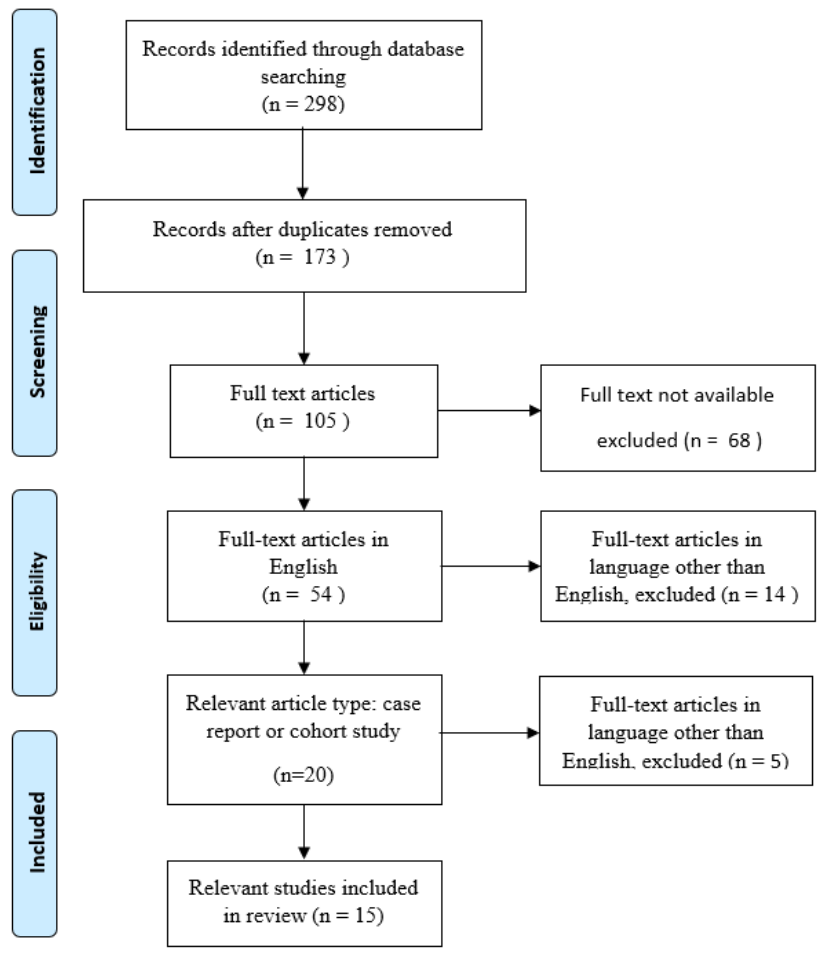

\section{RESULTS}

10 case reports and 5 cohort studies from 12 countries were reviewed with a total of 67 cases of cerebral disease reported in PXE patients ranging from ages 2 to 71 years. Publication years of the articles spanned from 1988-2020. The characteristics of PXE patients with neurovascular events from case studies vs cohort studies are listed in Tables 1 and 2 respectively. Overall, the most common neurovascular complications were ischemic strokes $(n=46,68.7 \%)$ followed by TIAs $(n=14,20.8 \%)$. There were $4(6.0 \%)$ reports of intracranial aneurysm formation and $3(4.5 \%)$ cases of hemorrhagic strokes. Of the 13 PXE subjects whose ischemic CVAs were 
Table 1. Characteristics of PXE patients with neurovascular complications across case studies

\begin{tabular}{|c|c|c|c|c|c|c|c|c|}
\hline Case report & Age & Male & Female & Country & $\begin{array}{c}\text { Ischemic } \\
\text { CVA }\end{array}$ & $\begin{array}{c}\text { Hemorrhagic } \\
\text { CVA }\end{array}$ & TIA & Aneurysm \\
\hline $\begin{array}{c}\text { Aralikatti et } \\
\text { al }^{12}\end{array}$ & 36 & 1 & 0 & $\begin{array}{l}\text { United } \\
\text { Kingdom }\end{array}$ & 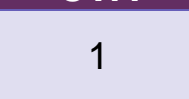 & (x) & 0 & 0 \\
\hline Araki et al ${ }^{13}$ & 63 & 1 & 0 & Japan & 1 & 0 & 0 & 0 \\
\hline $\begin{array}{l}\text { Bertamino et } \\
\mathrm{al}^{14}\end{array}$ & $\begin{array}{l}5 \\
2\end{array}$ & $\begin{array}{l}0 \\
1\end{array}$ & $\begin{array}{l}1 \\
0\end{array}$ & Italy & 2 & 0 & 0 & 0 \\
\hline Bock et al ${ }^{15}$ & 38 & 1 & 0 & Switzerland & 1 & 1 & 0 & 0 \\
\hline Defillo et al ${ }^{16}$ & NR & 0 & 2 & $\begin{array}{l}\text { United } \\
\text { States }\end{array}$ & 0 & 0 & 0 & 2 \\
\hline $\begin{array}{c}\text { Del Zotto et } \\
\text { al }^{17}\end{array}$ & 39 & 0 & 1 & Italy & 1 & 0 & 0 & 0 \\
\hline Hirano et al ${ }^{18}$ & $\begin{array}{l}47 \\
54 \\
62\end{array}$ & $\begin{array}{l}1 \\
0 \\
0\end{array}$ & $\begin{array}{l}0 \\
1 \\
1\end{array}$ & Japan & $\begin{array}{l}1 \\
1 \\
1\end{array}$ & $\begin{array}{l}0 \\
0 \\
0\end{array}$ & $\begin{array}{l}0 \\
0 \\
0\end{array}$ & $\begin{array}{l}0 \\
0 \\
0\end{array}$ \\
\hline Kumar et al ${ }^{19}$ & 65 & 1 & 0 & India & 1 & 0 & 0 & 1 \\
\hline $\begin{array}{l}\text { Lanfranconi } \\
\text { et al }{ }^{10}\end{array}$ & 62 & 1 & 0 & Italy & 1 & 0 & 0 & 0 \\
\hline $\begin{array}{c}\text { Pavlovic et } \\
\mathrm{al}^{20}\end{array}$ & $\begin{array}{l}47 \\
49 \\
71\end{array}$ & $\begin{array}{l}0 \\
1 \\
0\end{array}$ & $\begin{array}{l}1 \\
0 \\
1\end{array}$ & Serbia & $\begin{array}{l}1 \\
1 \\
1\end{array}$ & 0 & 1 & 0 \\
\hline
\end{tabular}

Table 2. Characteristics of included cohort studies and cross-sectional studies

\begin{tabular}{|c|c|c|c|c|c|c|c|}
\hline Study & $\begin{array}{c}\text { Mean } \\
\text { Age (SD) }\end{array}$ & $\begin{array}{l}\text { Male } \\
\text { sex } \%\end{array}$ & Country & $\begin{array}{l}\text { Study } \\
\text { Design }\end{array}$ & Cerebral disease & $\begin{array}{c}\text { PXE } \\
\text { patients }\end{array}$ & $\begin{array}{c}\text { Cerebral } \\
\text { disease n } \\
(\%)\end{array}$ \\
\hline $\begin{array}{c}\text { Kauw et } \\
\mathrm{al}^{21}\end{array}$ & $61(12)$ & 26 & Netherlands & PFU & $\begin{array}{c}\text { Ichemic CVA, } \\
\text { intracranial } \\
\text { hemorrhage, } \\
\text { intracranial } \\
\text { aneurysm }\end{array}$ & 178 & $31(17 \%)$ \\
\hline $\begin{array}{l}\text { Neldner } \\
\text { et } \mathrm{al}^{22}\end{array}$ & $\begin{array}{l}29.5 \\
(\mathrm{NR})\end{array}$ & 30 & USA/Canada & $\begin{array}{l}\text { Cross- } \\
\text { sectional }\end{array}$ & $\begin{array}{c}\text { Ruptured cerebral } \\
\text { aneurysm }\end{array}$ & 100 & $1(1 \%)$ \\
\hline $\begin{array}{c}\text { Omarjee } \\
\text { et } \mathrm{al}^{25}\end{array}$ & NR & NR & France & $\mathrm{RR}$ & $\begin{array}{c}\text { Ischemic CVA, } \\
\text { hemorrhagic CVA }\end{array}$ & 151 & $13(8.6 \%)$ \\
\hline $\begin{array}{c}\text { Van den } \\
\text { Berg et } \\
\mathrm{al}^{23}\end{array}$ & $\begin{array}{l}31.4 \\
\text { (NR) }\end{array}$ & 37 & Netherlands & PFU & Ischemic CVA & 94 & $8(8.5 \%)$ \\
\hline $\begin{array}{l}\text { Vanakker } \\
\text { et } \mathrm{al}^{24}\end{array}$ & 52 (NR) & 40 & Belgium & $\begin{array}{l}\text { Cross- } \\
\text { sectional }\end{array}$ & Ischemic CVA & 42 & $6(14 \%)$ \\
\hline
\end{tabular}

NR: not reported; PFU: Prospective follow-up; RR: Retrospective review 
Table 3. Reported neurovascular complications in PXE patients

\begin{tabular}{|c|c|c|c|c|c|}
\hline & $\begin{array}{c}\text { Ischemic } \\
\text { CVA, } \mathbf{n}(\%)\end{array}$ & $\begin{array}{c}\text { Hemorrhagic } \\
\text { CVA, } \mathbf{n}(\%)\end{array}$ & $\begin{array}{c}\text { TIA, } \mathbf{n} \\
(\%)\end{array}$ & $\begin{array}{c}\text { Intracranial } \\
\text { aneurysm, } \mathbf{n}(\%)\end{array}$ & $\begin{array}{c}\text { Total } \\
\mathbf{n}\end{array}$ \\
\hline $\begin{array}{c}\text { Neurovascular } \\
\text { complication }\end{array}$ & $46(68.7 \%)^{*}$ & $4(6.0 \%)$ & $\begin{array}{c}14 \\
(20.8 \%)\end{array}$ & $3(4.5 \%)$ & 67 \\
\hline Small artery & 12 & 0 & 0 & 0 & 12 \\
\hline Large artery & 2 & 0 & 0 & 0 & 2 \\
\hline
\end{tabular}

*Percentages are calculated over total \# of neurovascular complications in PXE patients (67)

attributed to a specific location of infarct, 12 $(92.3 \%)$ had infarctions in small arteries of the brain, whereas only 1 patient's CVA involved infarction of a large cerebral artery. (See Table 3 for summary of neurovascular complications)

Within the individual cohort studies, Van der Berg et al analyzed 100 patients affected by PXE, followed-up for 17.1 years, and found $8 \%$ incidence of stroke. ${ }^{23}$ Kauw et al found a comparable $8 \%$ incidence of stroke within their 178 PXE patient cohort. ${ }^{21}$ In their smaller 42 patient cohort, Vanakker et al found a $14 \%$ incidence of ischemic CVAs in their smaller cohort of 42 PXE patients. ${ }^{24}$

\section{DISCUSSION}

The pathogenesis of cardiovascular disease in PXE is characterized by progressive calcification in the medial layers of medium and small sized arteries. Previous studies have shown that pathogenic variants in the $A B C C 6$ gene are associated with an increased risk for ischemic stroke in humans. ${ }^{8}$ It is thus reasonable to hypothesize that PXE patients would therefore be at higher risk for ischemic and hemorrhagic neurovascular events when compared to the general population. Accordingly, individual cohort studies Van der Berg et al and Kauw et al found an 8\% prevalence for ischemic CVAs in PXE patients, compared to the $3 \%$ prevalence for ischemic CVAs seen in the general population. ${ }^{9}$ Relative risk of developing ischemic strokes is estimated to be 3.6 in PXE patients less than 65 years compared with the general population (95\% confidence interval 3.3-4.0). ${ }^{23,21}$ As demonstrated in Bertamino et al and Araki et al, an ischemic stroke can be a rare presenting symptom in both pediatric and adult cases of PXE. ${ }^{14,13}$ While an increased risk for neurovascular events in the general population warrants the initiation of prophylactic antiplatelet therapy, there is no current consensus on antiplatelet in PXE patients. ${ }^{5}$ While the 100 patient cohort in Van der Berg et. Al had 8 patients with ischemic CVAs, 17 patients from the same cohort developed serious gastrointestinal bleeding, one of whom suffered a fatal hemorrhage while taking aspirin. ${ }^{23}$

Liaqat et al reported a PXE patient who underwent successful coronary artery bypass surgery and was discharged on aspirin $81 \mathrm{mg}$ daily and apixaban $2.5 \mathrm{mg}$ BID without bleeding complications. ${ }^{5}$ Lanfranconi et al reported successful intravenous thrombolytic treatment of acute ischemic stroke in a 62 year old male PXE patient that resulted in resolution of neurological symptoms without bleeding complication. ${ }^{10}$ However, there were no case reports regarding use of aspirin as primary prevention for neurovascular events in PXE patients.

\section{CONCLUSION}

In conclusion, PXE patients are at higher risk than the general population for November 2020 Volume 4 Issue 6 
developing neurovascular disease, especially ischemic stroke. Clinicians should thus monitor PXE patients for neurological symptoms suggestive of neurovascular disease at visits. Given that bleeding complications are more common than ischemic stroke, anti-platelet therapy as primary prevention for PXE patients without known neurovascular disease is currently not recommended. Further studies must be conducted to determine the safety and efficacy of aspirin and thrombolytic therapy in the treatment and secondary prevention of neurovascular complications in PXE patients.

\section{Conflict of Interest Disclosures: None}

Funding: None

\section{Corresponding Author:}

Nancy W Wei

5 East $98^{\text {th }}$ Street, $5^{\text {th }}$ floor

New York, NY 10029

Phone: 212-241-7568

Fax: 212-987-1197

Email: nancy.wei@mountsinai.org

\section{References:}

1. Bergen, Arthur A. B., et al. "ABCC6 And Pseudoxanthoma Elasticum." Pflügers Archiv European Journal of Physiology, vol. 453, no. 5, 2006, pp. 685-691., doi:10.1007/s00424-0050039-0.

2. D'Marco L, Lima-Martínez M, Karohl C, Chacín M, Bermúdez V. Pseudoxanthoma Elasticum: An Interesting Model to Evaluate Chronic Kidney Disease-Like Vascular Damage without Renal Disease. Kidney Dis (Basel). 2020;6(2):92-97. doi:10.1159/000505026

3. Ringpfeil F, McGuigan K, Fuchsel L, et al. Pseudoxanthoma elasticum is a recessive disease characterized by compound heterozygosity. J Invest Dermatol.2006;126(4):782-786. doi:10.1038/sj.jid.5700115

4. Risseeuw S, Ossewaarde-van Norel J, van Buchem C, Spiering W, Imhof SM, van Leeuwen $R$. The extent of angioid streaks correlates with macular degeneration in pseudoxanthoma elasticum [published online ahead of print, 2020
Jul 20]. Am J Ophthalmol. 2020;S0002-

9394(20)30379-2. doi:10.1016/j.ajo.2020.07.022

5. Liaqat M, Heymann WR. Anticoagulation in

Patients with Pseudoxanthoma

Elasticum. Skinmed. 2017;15(4):319-320.

Published 2017 Aug 1.

6. Veken, Bieke Van Der, et al. "Development of Atherosclerotic Plaques in a Mouse Model of Pseudoxanthoma Elasticum." Acta Cardiologica, vol. 69 , no. 6, 2014, pp. 687-692., doi:10.1080/ac.69.6.1000012.

7. Roach, E. Steve, and Monica P. Islam. "Pseudoxanthoma Elasticum." Neurocutaneous Syndromes Handbook of Clinical Neurology, 2015, pp. 215-221., doi:10.1016/b978-0-44462702-5.00015-9.

8. De Vilder EYG, Cardoen S, Hosen MJ, et al. Pathogenic variants in the ABCC6 gene are associated with an increased risk for ischemic stroke. Brain Pathol. 2018;28(6):822-831. doi:10.1111/bpa.12620

9. Benjamin EJ, Virani SS, Callaway CW, et al. Heart Disease and Stroke Statistics-2018 Update: A Report From the American Heart Association [published correction appears in Circulation. 2018 Mar 20;137(12):e493]. Circulation. 2018;137(12):e67e492. 11

10. Lanfranconi S, Ghione I, Valcamonica G, Corti SP, Bonato S, Bresolin N. Safety and efficacy of rt-PA treatment for acute stroke in pseudoxanthoma elasticum: the first report [published online ahead of print, 2020 May 26]. $J$ Thromb Thrombolysis. 2020;10.1007/s11239020-02150-3. doi:10.1007/s11239-020-02150-3

11. Li Q, Guo H, Chou DW, et al. Warfarin accelerates ectopic mineralization in Abcc6(-/-) mice: clinical relevance to pseudoxanthoma elasticum. Am J Pathol. 2013;182(4):1139-1150. doi:10.1016/j.ajpath.2012.12.037

12. Aralikatti AK, Lee MW, Lipton ME, Kamath GG. Visual loss due to cerebral infarcts in pseudoxanthoma elasticum. Eye (Lond). 2002;16(6):785-786. doi:10.1038/sj.eye.6700173

13. Araki Y, Yokoyama T, Sagawa N, et al. Pseudoxanthoma elasticum diagnosed 25 years after the onset of cardiovascular disease. Intern Med. 2001;40(11):1117-1120. doi:10.2169/internalmedicine.40.1117

14. Bertamino M, Severino M, Grossi A, et al. ABCC6 mutations and early onset stroke: Two cases of a typical Pseudoxanthoma Elasticum. Eur J Paediatr Neurol. 2018;22(4):725-728. doi:10.1016/j.ejpn.2018.04.002 
15. Bock, Andreas, and Guido Schwegler.

"Intracerebral haemorrhage as first manifestation of Pseudoxanthoma elasticum." Clinical neurology and neurosurgery 110.3 (2008): 262264.

16. Defillo A, Nussbaum ES. Intracranial aneurysm formation in siblings with pseudoxanthoma elasticum: case report. J Neurosurg Sci. 2010;54(3):105-107.

17. Del Zotto E, Ritelli M, Pezzini A, et al. Clinical, neuroradiological and molecular features of a patient affected by pseudoxhantoma elasticum associated to carotid rete mirabile: case report. Clin Neurol Neurosurg. 2012;114(6):758761. doi:10.1016/j.clineuro.2011.12.031

18. Hirano T, Hashimoto Y, Kimura K, Uchino M. Rinsho Shinkeigaku. 1996;36(5):633-639.

19. Kumar GN, Ragi KV, Nair PS. Pseudoxanthoma elasticum with cerebrovascular accident. Indian J Dermatol Venereol Leprol. 2007;73(3):191-193. doi:10.4103/0378-6323.32746

20. Pavlovic AM, Zidverc-Trajkovic J, Milovic MM, et al. Cerebral small vessel disease in pseudoxanthoma elasticum: three cases. Can J Neurol Sci. 2005;32(1):115-118. doi:10.1017/s0317167100016991

21. Kauw F, Kranenburg G, Kappelle LJ, et al. Cerebral disease in a nationwide Dutch pseudoxanthoma elasticum cohort with a systematic review of the literature. J Neurol Sci. 2017;373:167-172. doi:10.1016/j.jns.2016.12.053

22. K.H. Neldner, Pseudoxanthoma elasticum, Clin. Dermatol. 6 (1) (1988) 1-159.

23. van den Berg JS, Hennekam RC, Cruysberg JR, et al. Prevalence of symptomatic intracranial aneurysm and ischaemic stroke in pseudoxanthoma elasticum. Cerebrovasc Dis. 2000;10(4):315-319. doi:10.1159/000016076

24. Vanakker, Olivier M., et al. "Novel ClinicoMolecular Insights in Pseudoxanthoma Elasticum Provide an Efficient Molecular Screening Method and a Comprehensive Diagnostic Flowchart." Wiley Online Library, John Wiley \& Sons, Ltd, 21 Dec. 2007, onlinelibrary.wiley.com/doi/10.1002/humu.9514/a bstract.

25. Omarjee L, Fortrat JO, Larralde A, et al. Internal Carotid Artery Hypoplasia: A New Clinical Feature in Pseudoxanthoma Elasticum. J Stroke. 2019;21(1):108-111. doi:10.5853/jos.2018.02705 